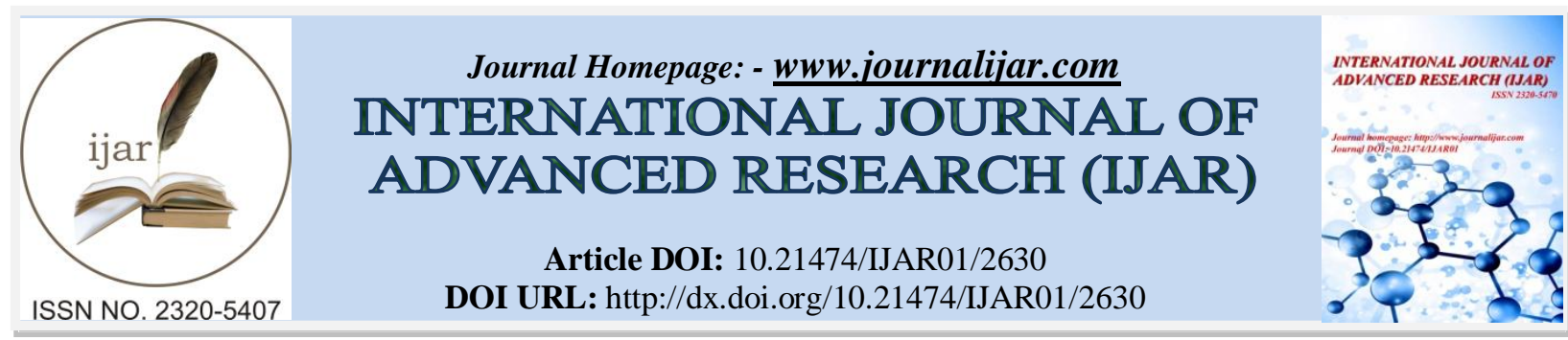

RESEARCH ARTICLE

\title{
STUDY OF RISK ABERRANT OF TYPE-2 DIABETES - CURRENT APPROACHES FOR CARE AND CONTROL.
}

\author{
*Amit Kumar Verma ${ }^{1,2}$, *Shahbaz Khan ${ }^{1}$, P.C Joshi ${ }^{2}$ and Kapil Dev ${ }^{1}$. \\ 1. Department of Biotechnology, Jamia Millia Islamia University, New Delhi. India. \\ 2. Department of Zoology and Environmental Science, Gurukula Kangri Vishwavidyalaya, Haridwar, India. \\ $3 *$ Equal Contribution.
}

\section{Manuscript Info}

\section{Manuscript History}

Received: 30 October 2016

Final Accepted: 29 November 2016

Published: December 2016

Key words:-

Type-2 Diabetes, dyslipidemia, complications, ethnicity, genetic factor, epidemiology.

\section{Abstract}

Prevalence of type 2 diabetes mellitus (T2DM) is increasing globally and has reached epidemic proportions in many countries. Type 2 diabetes is a complex disorder resulting from an interaction between genes and environment. Several risk factors for type 2 diabetes have been identified, including age, sex, obesity and central obesity, low physical activity, smoking, diet including low amount of fiber and high amount of saturated fat, ethnicity, family history, history of gestational diabetes mellitus, history of the non-diabetic elevation of fasting or 2-h glucose, elevated blood pressure, dyslipidemia, and different drug treatments. It occurs due to $\beta$ - cell dysfunction. Type 2 diabetes and its complications constitute a major worldwide public health problem, affecting almost all populations in both developed and developing countries with high rates of diabetes-related morbidity and mortality. The prevalence of type 2 diabetes has been increasing exponentially, and a high prevalence rate has been observed in developing countries. Multiple risk factors of diabetes, delayed diagnosis until micro- and macro-vascular complications arise, lifethreatening complications, failure of the current therapies, and financial costs for the treatment of this disease, make it necessary to develop new efficient strategies and appropriate prevention measures for the control of type 2 diabetes. In our current understanding about the epidemiology of type 2 diabetes, the roles of genes, lifestyle and other factors contributing to rapid increase in the incidence of type 2 diabetes. The core aims are to bring forward the new strategies for care and control type 2 diabetes.

Copy Right, IJAR, 2016,. All rights reserved.

\section{Introduction:-}

Diabetes mellitus is one of the oldest diseases known to mankind. This was first mentioned in Egyptian manuscript about 3000 years ago (1). In 1936, the difference between type 1 and type 2 Diabetes was clearly identified. Type 2 Diabetes was first described as a component of metabolic syndrome in 1988. It is also known as non-insulin dependent diabetes and is the most common form of diabetes characterized by hyperglycemia, insulin resistance, and relative insulin deficiency which results from interaction between genetic, environmental and behavioral risk factors.(2). In North American prevalence of diabetes mellitus reached 10.2\% in 2010, and is estimated to reach 
$12.1 \%$ by 2030 . This is an increase of $42.4 \%$ in the number of adults who will have diabetes. In the United States, (2004/06) national survey data indicated that the prevalence of diabetes was greater in non Hispanic Blacks (11.8\%) and Hispanics (10.4\%) compared to non-Hispanic whites (6.6\%). In Ontario, the most populated province in Canada, the Black population has higher rates of diabetes (11.6\%) than the White population $7.3 \%$ (2). Indian scenario is more serious being a developing nation majority of population belongs to middle class and death associated with diabetes is more than $80 \%$ in countries with low and middle income population (Global Health Estimates Geneva, WHO, 2014). India already house highest number of diabetic patients, and which is estimated to double by 2030 (3). Person with type 2 Diabetes are more vulnerable to various forms of both short and long-term complications, which often lead to their premature death. This tendency of increased morbidity and mortality is seen in patients with type 2 diabetes because of its insidious onset and late recognition, especially in resource-poor developing countries like India, Nepal, Bhutan, Sri Lanka, etc. It occurs due to $\beta$ - cell dysfunction.

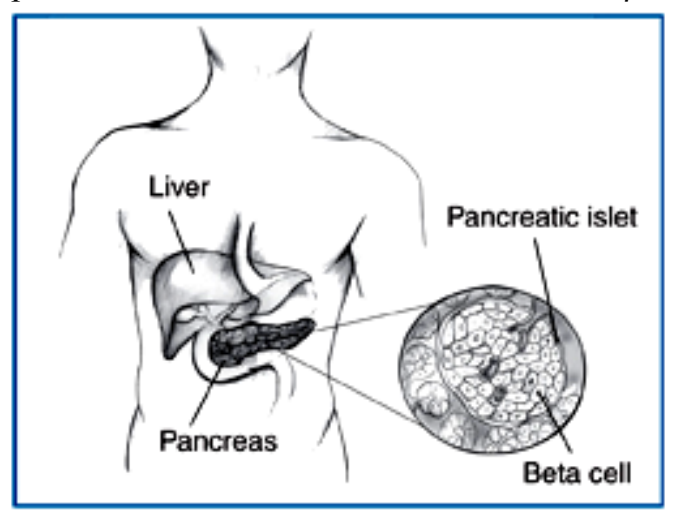

Figure.1:- Islets within the pancreas contain beta cells, which make insulin and release it into the blood.(21).(Diabetes Spectrum 2002 (15).

\section{B-cell dysfunction:-}

$\beta$-cell resides in pancreas, where they perform important function of producing insulin for body. $\beta$-cell secrete insulin when they are signaled to do so by increasing glucose level in blood. Without adequate insulin, blood glucose level increases, this is a defining characteristic of any type of Diabetes. In type 2 diabetes, $\beta$-cells churn out a lot of insulin early in the disease process, hence characterized by both high glucose level and high insulin level in blood. This is now clearly evident by the findings of Staigeret al., (2013)(3) that among the 27 confirmed and potential diabetes risk genes, 18 genes affect $\beta$-cell function, which are as follows: CAPN10 , CDC123/CAMK1D ,CDKAL1, CDKN2A/B , ENPP1, FOXO1,HHEX, IGF2BP2, JAZF1 , KCNJ11,KCNQ1, MTNR1B ,PPARGC1A , SGK1, SLC3OA8,TCF7L2, TSPAN8/LGR5 and WFS1 .

\section{Responsible factors for T2D:-}

Several previous studies showed that there are many factors such as genetic, environmental, Chemical etc. have great influence on T2D.

\section{Genetic Factors:-}

GWAS study showed that there are many genetic factors play important role in prevalence of T2D. The susceptibility loci of T2DM have been discovered by genome-wide association studies (GWAS) since early 2007 (4). Then, numerous GWAS conducted in different countries and ethnic groups have reported linkage signals at the same or different chromosomes with T2DM, and have successfully identified approximately 75 susceptibility loci related to T2DM. Epigenetics refers to heritable changes in gene function that occur without a change in nucleotide sequence. Mechanisms like DNA-methylation, histone acetylation and non-coding RNAs are used by the cell to regulate gene expression in response to environmental cues and can persist for an individual's lifetime and can be passed on over 2-3 generations. 
Figure 2:- Different genetic variants of T2D. (GWAS). Over the years, type 2 diabetes mellitus (T2D) genome-wide

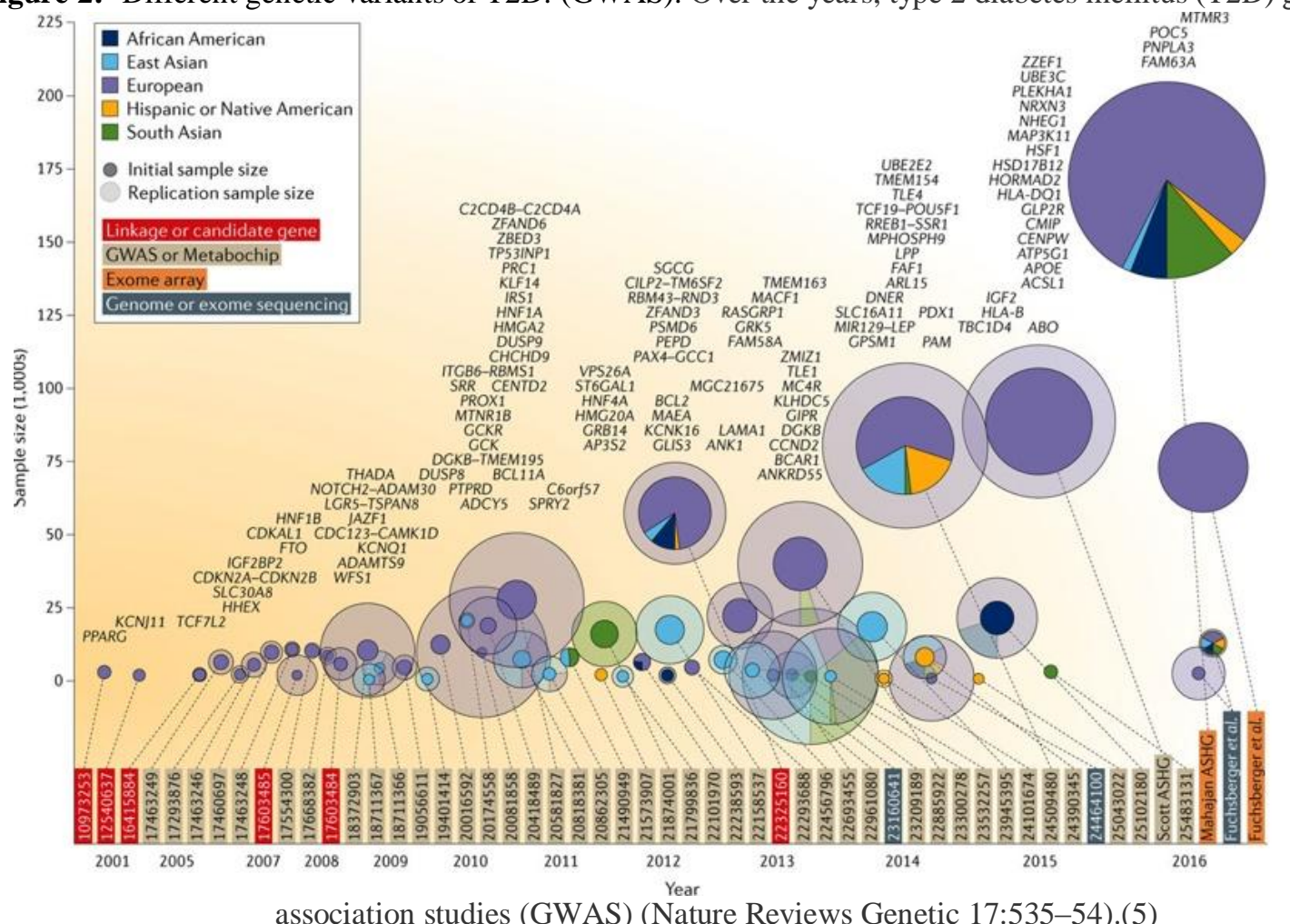

\section{Some examples of candidate genes are:-}

CDKAL1 Although the function of CDKAL1 is still unclear, this protein is similar to cyclin-dependent kinase 5 regulatory subunit-associated protein1 (CDK5RAP1), which is expressed in neuronal tissues, and inhibits CDK5 activity by binding to the CDK5 activator. CDK5 has been shown to blunt insulin secretion in response to glucose and to play a permissive role in the decrease of insulin gene expression, suggesting that CDKAL1 plays a role in $\beta$ cell function by inhibiting activity of CDK5. CDKN2A/BCDKN2A and CDKN2B are adjacent cyclin-dependent kinase inhibitor genes on chromosome 9p. CDKN2A inhibits CDK4, a key regulator of pancreatic beta cell replication. HHEX (Hematopoietically expressed homeobox protein) that in human is encoded by HHEX gene, this gene encodes a member of homeobox family of transcription factors, many of which are involved in the developmental process. IGF2BP2Insulin like growth factor 2 mRNA binding protein 2 gene is involved in insulin secretion essential for glucose metabolism, this gene have shown conflicting results regarding the nature of association of type 2 Diabetes. KCNJ11 (potassium inwardly rectifying channel, subfamily J, member 11), TCF7L2 (transcription factor 7-like 2, the strongest T2D locus identified to date), IRS1 (insulin receptor substrate 1), MTNR1B (melatonin-receptor gene), PPARG2 (peroxisome proliferator-activated receptor gamma 2), FTO (fat mass and obesity associated) gene. van Exel and his group found that low IL-10 production capacity is also associated with T2DM (6). It is worth highlighting that IL-10-1082A/G polymorphism is associated with T2DM susceptibility in Asians, but not in Europeans and Africans, which may be ascribable to various genetic background and environmental exposures (7).Among these susceptible loci, KCNJ11 encodes the islet ATP-sensitive potassium channel Kir6. TCF7L2 regulates proglucagon gene expression and produces glucagon-like peptide(8).IRS1 has an effect on insulin action (9). MTNR1B is correlated with endogenous ligand melatonin that mediates circadian rhythm and affects metabolic regulation (9). PPARG2 encodes a transcription factor for adipocyte differentiation (10); IGF2BP2 is involved in pancreas development, growth and stimulation of insulin action (10). HHEX affects $\beta$ cell development; and FTO predisposes to diabetes through acting on BMI (Body Mass Index) (11). Meanwhile, many of these loci are some important susceptibility loci are listed in Table 1. 
Table 1:- Genetic variants associated withT2D (GWAS) (12).

\begin{tabular}{|c|c|c|c|c|c|c|c|}
\hline LOCUS & MARKER & $\begin{array}{l}\mathrm{CH} \\
\mathrm{R} .\end{array}$ & $\begin{array}{c}\text { TYPE OF } \\
\text { MUTATION }\end{array}$ & $\begin{array}{c}\text { EFFECT } \\
\text { (ALLELE/OT } \\
\text { HER) }\end{array}$ & $\begin{array}{c}\text { EFFECT } \\
\text { ALLELE } \\
\text { FREQUENCY(H } \\
\text { apMap-CEU) }\end{array}$ & $\begin{array}{c}\text { TRAI } \\
\mathrm{T}\end{array}$ & $\begin{array}{c}\text { EFFECT } \\
\text { OR/Beta } \\
(95 \% \\
\text { CI/SE) }\end{array}$ \\
\hline PPARG & rs1801282 & 3 & $\begin{array}{l}\text { Missense } \\
\text { Pro 12Ala }\end{array}$ & $\mathrm{C} / \mathrm{G}$ & 0.92 & T2D & $\begin{array}{c}1.14(1.0 \\
8- \\
1.20)^{15-17}\end{array}$ \\
\hline $\begin{array}{c}\mathrm{KCNJ} 11 / \mathrm{ABC} \\
\mathrm{C} 8\end{array}$ & $\begin{array}{c}\text { rs5219/rs757 } \\
110^{\mathrm{a}, 5}\end{array}$ & 11 & $\begin{array}{c}\text { Missense } \\
\text { Glu23Lys/Ala1 } \\
\text { 369Ser }\end{array}$ & $\begin{array}{l}\mathrm{T} / \mathrm{C} \\
\mathrm{G} / \mathrm{T}\end{array}$ & $\begin{array}{l}0.50 \\
0.40\end{array}$ & T2D & $\begin{array}{l}1.15(1.0 \\
9-1.21)^{17}\end{array}$ \\
\hline TCF7L2 & $\begin{array}{c}\text { rs } 7903146^{b, 3,} \\
\text { rs12243326 } \\
36\end{array}$ & 10 & $\begin{array}{l}\text { Intronic } \\
\text { Intronic }\end{array}$ & $\begin{array}{l}\mathrm{T} / \mathrm{C} \\
\mathrm{C} / \mathrm{T}\end{array}$ & $\begin{array}{l}0.25 \\
0.21\end{array}$ & $\begin{array}{c}\text { T2D } \\
\text { FG } \\
\text { 2-hrG }\end{array}$ & $\begin{array}{c}1.37(1.2 \\
8-1.47)^{18} \\
0.07(0.0 \\
1)\end{array}$ \\
\hline IGF2BP2 & $\begin{array}{c}\text { rs4402960 } \\
17\end{array}$ & 3 & Intronic & $\mathrm{T} / \mathrm{G}$ & 0.29 & T2D & $\begin{array}{l}1.17(1.1 \\
0-1.25)^{18}\end{array}$ \\
\hline CDKAL1 & $\begin{array}{c}\text { rs7754840 } \\
17\end{array}$ & 6 & Intronic & $\mathrm{C} / \mathrm{G}$ & 0.31 & $\mathrm{~T} 2 \mathrm{D}$ & $\begin{array}{l}1.12(1.0 \\
8-1.16)\end{array}$ \\
\hline SLC30A8 & $\underset{, 35}{\operatorname{rs} 13266634^{13}}$ & 8 & $\begin{array}{c}\text { Missense } \\
\text { Arg325Trp }\end{array}$ & $\mathrm{C} / \mathrm{T}$ & 0.75 & $\begin{array}{l}\text { T2D } \\
\text { FG }\end{array}$ & $\begin{array}{c}1.12(1.0 \\
7-1.16)^{65} \\
0.027(0 . \\
004)\end{array}$ \\
\hline CDKA2A/B & $\underset{-17}{\operatorname{rs} 10811661^{15}}$ & 9 & $\begin{array}{c}125 \mathrm{~kb} \\
\text { upstream }\end{array}$ & $\mathrm{T} / \mathrm{C}$ & 0.79 & T2D & $\begin{array}{l}1.20(1.1 \\
4-1.25)\end{array}$ \\
\hline HHEX & rs1111875 & 10 & $\begin{array}{c}7.7 \mathrm{~kb} \\
\text { downstream }\end{array}$ & $\mathrm{C} / \mathrm{T}$ & 0.56 & T2D & $\begin{array}{l}1.13(1.0 \\
8-1.17)^{17}\end{array}$ \\
\hline FTO & $\underset{6}{\mathrm{rs} 8050136^{15,1}}$ & 16 & Intronic & $\mathrm{A} / \mathrm{C}$ & 0.45 & $\mathrm{~T} 2 \mathrm{D}$ & $\begin{array}{l}1.15(1.0 \\
9-1.22)^{18}\end{array}$ \\
\hline HNF1B & $\underset{11}{\operatorname{rs} 757210^{110,1}}$ & 17 & Intronic & $\mathrm{A} / \mathrm{G}$ & 0.43 & $\mathrm{~T} 2 \mathrm{D}$ & $\begin{array}{l}1.12(1.0 \\
7-1.18)^{65}\end{array}$ \\
\hline NOTCH2 & rs10923931 ${ }^{18}$ & 1 & Intronic & $\mathrm{T} / \mathrm{G}$ & 0.11 & T2D & $\begin{array}{l}1.13(1.0 \\
8-1.17)\end{array}$ \\
\hline THADA & rs $7578597^{18}$ & 2 & $\begin{array}{c}\text { Missense } \\
\text { Thr1187Ala }\end{array}$ & $\mathrm{T} / \mathrm{C}$ & 0.92 & $\mathrm{~T} 2 \mathrm{D}$ & $\begin{array}{c}1.15(1.1 \\
0-1.20)\end{array}$ \\
\hline ADAMSTS9 & rs4607103 & 3 & $38 \mathrm{~kb}$ upstream & $\mathrm{C} / \mathrm{T}$ & 0.81 & T2D & $\begin{array}{c}1.09(1.0 \\
6-1.12)\end{array}$ \\
\hline JAZF1 & rs8864745 $5^{18}$ & 7 & Intronic & $\mathrm{T} / \mathrm{C}$ & 0.52 & T2D & $\begin{array}{c}1.10(1.0 \\
7-1.13)\end{array}$ \\
\hline GCK & Rs4607517 35 & 7 & $36 \mathrm{~kb}$ upstream & $\mathrm{A} / \mathrm{G}$ & 0.20 & $\begin{array}{c}\mathrm{FG} \\
\mathrm{HbA}_{1} \\
\mathrm{c} \\
\mathrm{T} 2 \mathrm{D}\end{array}$ & $\begin{array}{c}0.02(0.0 \\
04) \\
0.041(0 . \\
005) \\
1.07(1.0 \\
5-1.10)\end{array}$ \\
\hline KLF14 & Rs972283 ${ }^{65}$ & 7 & $47 \mathrm{~kb}$ upstream & $\mathrm{G} / \mathrm{A}$ & 0.55 & T2D & $\begin{array}{c}1.07(1.0 \\
5-1.10) \\
\end{array}$ \\
\hline TP33INP1 & Rs896854 ${ }^{65}$ & 8 & Intronic & $\mathrm{T} / \mathrm{C}$ & 0.48 & T2D & $\begin{array}{c}1.06(1.0 \\
4-1.09)\end{array}$ \\
\hline GLIS3 & Rs7034200 35 & 9 & Intronic & $\mathrm{A} / \mathrm{C}$ & 0.53 & $\begin{array}{c}\text { FG } \\
\text { HOM } \\
\text { A-B }\end{array}$ & $\begin{array}{c}0.018(0 . \\
003) \\
- \\
0.020(0 . \\
004)\end{array}$ \\
\hline
\end{tabular}




\begin{tabular}{|c|c|c|c|c|c|c|c|}
\hline TLE48 & $\operatorname{Rs}_{5}{ }^{292136^{6}}$ & 9 & $\begin{array}{c}234 \mathrm{~kb} \\
\text { upstream }\end{array}$ & $\mathrm{C} / \mathrm{T}$ & 0.93 & T2D & $\begin{array}{l}1.11(1.0 \\
7-1.15)\end{array}$ \\
\hline ADRA2A & $\underset{5}{\mathrm{Rs} 10885122^{3}}$ & 10 & $\begin{array}{c}210 \mathrm{~kb} \\
\text { downstream }\end{array}$ & $\mathrm{G} / \mathrm{T}$ & 0.90 & FG & $\begin{array}{c}0.022(0 . \\
004)\end{array}$ \\
\hline CENTD2 & Rs1552224 & 11 & 5'UTR & $\mathrm{A} / \mathrm{C}$ & 0.88 & T2D & $\begin{array}{l}1.14(1.1 \\
1-1.17)\end{array}$ \\
\hline CRY2 & $\mathrm{Rs}_{5}^{11695924^{3}}$ & 11 & Intronic & $\mathrm{A} / \mathrm{C}$ & 0.54 & FG & $\begin{array}{c}0.015(0 . \\
03)\end{array}$ \\
\hline FADS1 & Rs $174550^{35}$ & 11 & Intronic & $\mathrm{T} / \mathrm{C}$ & 0.63 & $\begin{array}{c}\text { FG } \\
\text { HOM } \\
\text { A-B }\end{array}$ & $\begin{array}{c}0.17(0.0 \\
03) \\
0.020(0 . \\
003) \\
\end{array}$ \\
\hline MADD & Rs7944584 $^{35}$ & 11 & Intronic & $\mathrm{A} / \mathrm{T}$ & 0.59 & FG & $\begin{array}{c}0.021(0 . \\
03)\end{array}$ \\
\hline MTNR1B & $\underset{5}{R s 10830963^{3}}$ & 11 & Intronic & $\mathrm{G} / \mathrm{C}$ & 0.30 & $\begin{array}{c}\mathrm{FG} \\
\mathrm{HOM} \\
\mathrm{A}-\mathrm{B} \\
\mathrm{HbA}_{1} \\
\mathrm{C} \\
\mathrm{T} 2 \mathrm{D}\end{array}$ & $\begin{array}{c}0.067(0 . \\
003) \\
- \\
0.034(0 . \\
004) \\
0.024(0 . \\
004) \\
1.09(1.0 \\
6-1.12) \\
\end{array}$ \\
\hline HMGA2 & Rs1531343 ${ }^{65}$ & 12 & $43 \mathrm{~kb}$ upstream & $\mathrm{C} / \mathrm{G}$ & 0.10 & T2D & $\begin{array}{l}1.10(1.0 \\
7-1.14)\end{array}$ \\
\hline HNF1A & Rs7957197 & 12 & $\begin{array}{c}20 \mathrm{~kb} \\
\text { downstream }\end{array}$ & T/A & 0.85 & T2D & $\begin{array}{l}1.07(1.0 \\
5-1.10)\end{array}$ \\
\hline IGF1 & Rs35767 35 & 12 & $\begin{array}{c}1.2 \mathrm{~kb} \\
\text { downstream }\end{array}$ & G/A & 0.90 & $\begin{array}{c}\text { F1 } \\
\text { HOM } \\
\text { A-IR }\end{array}$ & $\begin{array}{c}0.01(0.0 \\
06) \\
0.013(0 . \\
006)\end{array}$ \\
\hline C2CD4B & $\underset{5}{\mathrm{Rs} 11071657^{3}}$ & 15 & $\begin{array}{c}21 \mathrm{~kb} \\
\text { downstream }\end{array}$ & $\mathrm{A} / \mathrm{G}$ & 0.59 & FG & $\begin{array}{c}0.008(0 . \\
003)\end{array}$ \\
\hline PRC1 & Rs8042680 & 15 & Intronic & $\mathrm{A} / \mathrm{C}$ & 0.22 & T2D & $\begin{array}{l}1.07(1.0 \\
5-1.09)\end{array}$ \\
\hline VPS13C & $\operatorname{Rs}_{6} \underset{6}{271305^{3}}$ & 15 & Intronic & G/A & 0.42 & 2-hrG & $\begin{array}{c}0.07(0.0 \\
1)\end{array}$ \\
\hline ZFAND6 & $\operatorname{Rs}_{5} 1634397^{6}$ & 15 & $\begin{array}{c}1.5 \mathrm{~kb} \\
\text { downstream }\end{array}$ & G/A & 0.56 & T2D & $\begin{array}{l}1.06(1.0 \\
4-1.08)\end{array}$ \\
\hline GIPR & Rs10423928 & 19 & Intronic & $\mathrm{A} / \mathrm{T}$ & 0.18 & 2-hrG & $\begin{array}{c}0.11(0.0 \\
1)\end{array}$ \\
\hline $\begin{array}{c}\text { CDC123/CA } \\
\text { MK1D }\end{array}$ & $\underset{8}{\mathrm{Rs} 12779790^{1}}$ & 10 & $\begin{array}{l}\text { Intergenic } \\
\text { region }\end{array}$ & G/A & 0.23 & T2D & $\begin{array}{l}1.11(1.0 \\
7-1.14)\end{array}$ \\
\hline KCNQ1 & $\begin{array}{c}\text { Rs2237892 } \\
4 \\
\text { Rs2231362 } \\
\text { c,65 }\end{array}$ & 11 & Intronic & $\begin{array}{l}\mathrm{C} / \mathrm{T} \\
\mathrm{G} / \mathrm{A}\end{array}$ & $\begin{array}{l}0.61^{\mathrm{d}} \\
0.52\end{array}$ & $\begin{array}{l}\text { T2D } \\
\text { T2D }\end{array}$ & $\begin{array}{c}1.4(1.34- \\
1.47) \\
1.08(1.0 \\
6-1.10)\end{array}$ \\
\hline $\begin{array}{c}\text { TSPAN8/LG } \\
\text { R5 }\end{array}$ & Rs7961581 $^{18}$ & 12 & Intronic & $\mathrm{C} / \mathrm{T}$ & 0.23 & T2D & $\begin{array}{l}1.09(1.0 \\
6-1.12)\end{array}$ \\
\hline IRS1 & Rs2943641 & 2 & $\begin{array}{c}502 \mathrm{~kb} \\
\text { upstream }\end{array}$ & $\mathrm{C} / \mathrm{T}$ & 0.61 & T2D & $\begin{array}{l}1.19(1.1 \\
3-1.25)\end{array}$ \\
\hline DUSP9 & Rs5945326 & $\mathrm{X}$ & $8 \mathrm{~kb}$ upstream & G/A & 0.12 & $\mathrm{~T} 2 \mathrm{D}$ & $\begin{array}{l}1.27(1.1 \\
8-1.37)\end{array}$ \\
\hline PROX1 & Rs340874 ${ }^{35}$ & 1 & $2 \mathrm{~kb}$ upstream & $\mathrm{C} / \mathrm{T}$ & 0.50 & $\begin{array}{l}\text { FG } \\
\text { T2D }\end{array}$ & $\begin{array}{c}0.013(0 . \\
003\end{array}$ \\
\hline
\end{tabular}




\begin{tabular}{|c|c|c|c|c|c|c|c|}
\hline & & & & & & & $\begin{array}{l}1.07(1.0 \\
5-1.09)\end{array}$ \\
\hline BCL11A & Rs243021 ${ }^{65}$ & 2 & $\begin{array}{c}99 \mathrm{~kb} \\
\text { downstream }\end{array}$ & $\mathrm{A} / \mathrm{G}$ & 0.46 & T2D & $\begin{array}{l}1.08(1.0 \\
6-1.10)\end{array}$ \\
\hline G6PC2 & Rs560887 ${ }^{35}$ & 2 & Intronic & $\mathrm{C} / \mathrm{T}$ & 0.70 & $\begin{array}{c}\mathrm{FG} \\
\mathrm{HOM} \\
\mathrm{A}-\mathrm{B} \\
\mathrm{Hba}_{1 \mathrm{C}}\end{array}$ & $\begin{array}{c}0.075(0 . \\
004) \\
- \\
0.042(0 . \\
004) \\
0.032(0 . \\
004)\end{array}$ \\
\hline GCKR & $\begin{array}{c}\text { Rs1260326, } \\
7 \\
\text { Rs780094 }\end{array}$ & 2 & $\begin{array}{l}\text { Missense } \\
\text { Leu446Pro } \\
\text { Intronic }\end{array}$ & $\begin{array}{l}\mathrm{T} / \mathrm{C} \\
\mathrm{C} / \mathrm{T}\end{array}$ & $\begin{array}{c}0.40 \\
0.062\end{array}$ & $\begin{array}{c}\text { 2-hr- } \\
\text { G } \\
\text { FG } \\
\text { F1 } \\
\text { HOM } \\
\text { A-IR } \\
\text { T2D }\end{array}$ & $\begin{array}{c}0.10(0.0 \\
1) \\
0.029(0 . \\
003) \\
0.032(0 . \\
004) \\
0.035(0 . \\
004) \\
1.06(1.0 \\
4-1.08)\end{array}$ \\
\hline ADCY5 & $\begin{array}{c}\text { Rs2877716 } \\
6,81 \\
\text { ent,35 }\end{array}$ & 3 & $\begin{array}{l}\text { Intronic } \\
\text { Intronic }\end{array}$ & $\begin{array}{l}\mathrm{C} / \mathrm{T} \\
\mathrm{A} / \mathrm{G}\end{array}$ & $\begin{array}{l}0.77 \\
0.78\end{array}$ & $\begin{array}{c}\text { 2-hr- } \\
\text { G } \\
\text { FG } \\
\text { HOM } \\
\text { A-B } \\
\text { T2D }\end{array}$ & $\begin{array}{c}0.07(0.0 \\
1) \\
0.027(0 . \\
003) \\
- \\
0.023(0 . \\
004) \\
1.12(1.0 \\
9-1.15)\end{array}$ \\
\hline SLC2A2 & $\underset{5}{R s 11920090^{3}}$ & 3 & Intronic & T/A & 0.85 & FG & $\begin{array}{c}0.02(0.0 \\
04)\end{array}$ \\
\hline A/GWFS1 & Rs1801214 ${ }^{65}$ & 4 & $\begin{array}{l}\text { Intron-exon } \\
\text { junction }\end{array}$ & G/A & 0.27 & T2D & $\begin{array}{l}1.13(1.0 \\
7-1.18)\end{array}$ \\
\hline ZBED3 & Rs4457053 ${ }^{65}$ & 5 & $41 \mathrm{~kb}$ upstream & G/A & 0.26 & $\mathrm{~T} 2 \mathrm{D}$ & $\begin{array}{l}1.08(1.0 \\
6-1.11)\end{array}$ \\
\hline $\begin{array}{c}\text { DGKB/TME } \\
\text { M195 }\end{array}$ & Rs2191349 35 & 7 & $\begin{array}{l}\text { Intergenic } \\
\text { region }\end{array}$ & $\mathrm{T} / \mathrm{G}$ & 0.47 & $\begin{array}{c}\text { FG } \\
\text { T2D }\end{array}$ & $\begin{array}{c}0.03(0.0 \\
03) \\
1.06(1.0 \\
4-1.08)\end{array}$ \\
\hline
\end{tabular}

\section{Environmental Factors:-}

The number of people with diabetes has tripled in only 30 years. People's genes have not changed in 30 years. What has changed is the environment we live in. That's where all the Type 2 diabetes (and the high blood pressure and heart disease) is coming from. Environment plays a key role in the prevalence of T2D. There are many environmental factors such as Temperature, air, altitudinal variations, chemicals, pollutions etc. that are directly or indirectly related to the T2D.

\section{Unhealthful food:-}

Intake of large quantities of refined carbohydrates the "white things," such as sweets, breads, pastas, etc. Disturb the natural process of food digestion and absorption. They raise serotonin (13) and dopamine levels, making your blood glucose drops and you feel miserable again. 


\section{Physical activity:-}

Many studies suggested that less physical activity is one of the important reason for T2D.People used to move their bodies in the course of work, food gathering, transportation, and recreation. Most of this is now done by machines, so they have to consciously seek physical activity.

\section{Stress;-}

Stress is the body's response to a threat (14), often called the "fight-or-flight" response. Stress hormones, particularly cortisol, raise blood glucose levels and blood pressure. They do this so muscles involved in fight or flight will have enough fuel. Under stress, only the cells actually being used to run away or fight will open to insulin. Other cells close off (become "insulin resistant") to save the glucose fuel for the cells that are working. Stress also causes the liver to release even more glucose into the blood for fight or flight.

\section{Social isolation:-}

People don't realize how social mobility and moving all the time endangers health. Social isolation is increasing (15), and it is stressful. Loneliness (16) may be the number one cause of premature death. Humans are primates, and like all the apes, we feel better and stronger when we have other people on our side.

\section{Pollution:-}

Different type of the pollution ( Noise, Air, Water etc. ) have potential to increase the prevalence of T2D.Epidemiologic evidence shows a positive association between air pollution and T2D risk $(17,18)$.Effect of inhaled pollutants that are supported by experimental and epidemiological evidence include the contribution to systemic inflammation, autonomic imbalance, weight gain and to insulin resistance, thought to be in part the result of inhalants stimulating an innate immune response, influencing endoplasmic reticulum, glucose and lipid metabolism and activating the central nervous system.(19)

\section{Exposure to chemical pollution:-}

Chemical pollution may be harder to avoid. And since nobody knows for sure if a particular case of diabetes is caused by pollution, Chemicals in food, water, plastic packaging, and cleaning and beauty care products have all been found to increase insulin resistance and diabetes. These risks are not evenly spread through society. People with less money, less education, and less social status usually have less access to healthful food. They also have more barriers to exercise, more stress, and often more exposure to chemicals. People who have had hard lives, like a history of trauma or a difficult childhood, also have more of these risk factors.

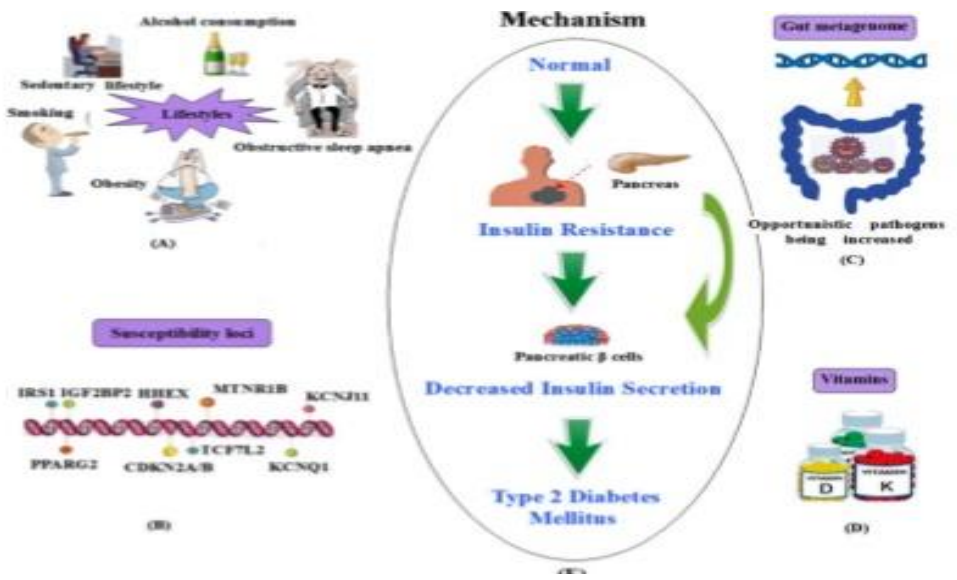

Figure.3:- A summary of the influencing factors and mechanism of T2DM. (A) Lifestyles; (B) Susceptibility loci; (C) Gut metagenome association; (D) Vitamins. (E) The mechanism of T2DM. (Ijms.1185-1200. 2014. (20). 


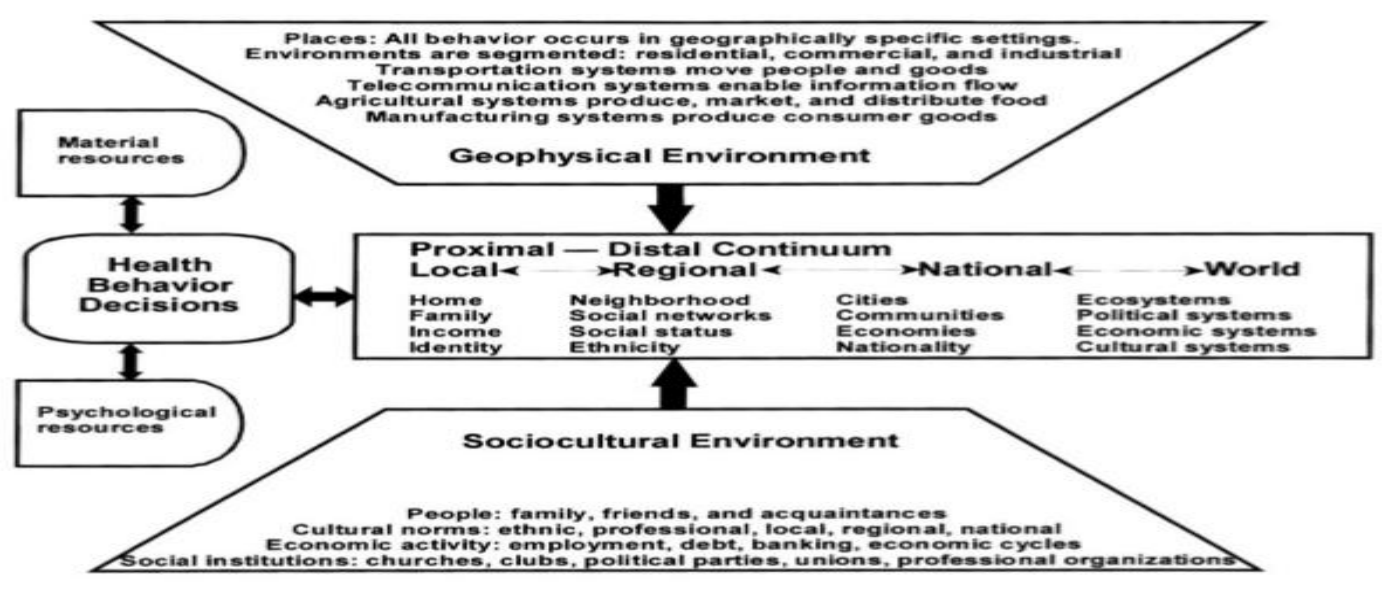

Figure 4:- A theoretical model showing how our environmental factors affect health behaviours. (Diabetes Spectrum 2002 (15).(21)

People who develop type 2 diabetes are more likely to have the following characteristics:

- $\quad$ age 45 or older

- overweight or obese

- physically inactive

- parent or sibling with diabetes

- family background that is African American, Alaska Native, American Indian, Asian American, Hispanic/Latino, or Pacific Islander American

- history of giving birth to a baby weighing more than 9 pounds

- history of gestational diabetes

- high blood pressure - $140 / 90$ or above — or being treated for high blood pressure

- high-density lipoprotein (HDL), or good, cholesterol below 35 milligrams per deciliter (mg/dL), or a triglyceride level above $250 \mathrm{mg} / \mathrm{dL}$

- polycystic ovary syndrome, also called PCOS

- $\quad$ prediabetes - an A1C level of 5.7 to 6.4 percent; a fasting plasma glucose test result of $100-125 \mathrm{mg} / \mathrm{dL}$, called impaired fasting glucose; or a 2-hour oral glucose tolerance test result of 140-199, called impaired glucose tolerance

- acanthosis nigricans, a condition associated with insulin resistance, characterized by a dark, velvety rash around the neck or armpits

- history of CVD

The American Diabetes Association (ADA) recommends that testing to detect prediabetes and type 2 diabetes be considered in adults who are overweight or obese and have one or more additional risk factors for diabetes. In adults without these risk factors, testing should begin at age 45 . $(55,56)$

\section{Life style factors:-}

A variety of lifestyle factors such as sedentary lifestyle (22)physical inactivity (23), smoking (24), alcohol consumption(25), sexual inactivity and Mental stress. Current studies have shown that obesity is the most important risk factor for T2DM, which may influence the development of insulin resistance and disease progression (26). Nearly $90 \%$ of diabetic patients develop T2DM mostly relating to excess body weight according to the World Health Organization (WHO, 2011). Furthermore, obesity is strongly inherited (27). Junk food consumption in recent time is one of the major cause of obesity.

Pamidi et al. Explained that obstructive sleep apnea (OSA), a treatable sleep disorder that is pervasive among overweight and obese adults, has become a novel, modifiable risk factor relevant to insulin resistance and glucose intolerance, and may influence on the development of prediabetes (20\%-67\%) and T2DM (15\%-30\%), independent of shared risk factors $(28,29)$. In addition, diet is considered as a modifiable risk factor for T2DM. Studies have shown that a low-fiber diet with a high glycemic index is positively associated with a higher risk of T2DM (30), and 
specific dietary fatty acids may affect insulin resistance and the risk of diabetes in varying degrees (31). Total and saturated fat intake is associated with an increased risk of T2DM independently of BMI, but higher intake of linoleic acid has the opposite effect, especially among leaner and younger men (32). Frequent consumption of processed meat, but not other meats, may increase the risk of T2DM after adjustment for BMI, prior weight change, and alcohol and energy intake.(33). Soft drinks have also been bounded up with increased risk of T2DM (34) and metabolic syndrome (35), because they are directly associated with BMI (36).

\section{Gut metagenome factor:-}

Gut metagenomic markers show higher specificity for differentiation between T2DM cases and controls based on human genome variation, which may be a promising complementary approach to monitor gut health for risk assessment of this disease.

In some recent studies, gut metagenome was shown to be a factor for the development of T2DM (37). Various type of gut bacteria play important roles in maintaining or interacting with their environment. Two-stage metagenomewide association study (MGWAS) suggested that T2DM patients show a moderate degree of gutmicrobial dysbiosis, with various butyrate-producing bacteria being decreased (Clostridiales sp. SS3/4, Roseburiaintestinalis, Roseburiainulinivorans, Eubacteriumrectale and Faecalibacteriumprausnitzii) and some opportunistic pathogens being increased (Bacteroidescaccae, Clostridium hathewayi, Clostridium ramosum, Clostridium symbiosum, Eggerthellalenta and Escherichia coli). In T2DM patients, the gut microbiota presents enrichment in membrane transport of sugars, methane metabolism, branched-chain amino acid (BCAA) transport, xenobiotics degradation and metabolism, and sulphate reduction; and reduction in the level of bacterial chemotaxis, flagellar assembly, butyrate biosynthesis and metabolism of cofactors and vitamins. A study showed that seven of the T2DM-enriched KEGG orthologues markers were associated with oxidative stress resistance, including nitric oxide reductase (K02448), putative iron-dependent peroxidase (K07223), cytochrome c peroxidase (K00428), catalase (K03781), peroxiredoxin (K03386), Mn-containing catalase (K07217), and glutathione reductase (NADPH) (K00383), which were not seen in control-enriched KEGG orthologues markers (38). In addition, it was found that 14 KEGG orthologues markers, which were markedly up-regulated in T2DM patients, were related to drug resistance. These results demonstrated that T2DM patients may have a more hostile gut environment that stimulates defence mechanisms against microbes and oxidative stresses. There is a T2D classifier system based on gut microbiota, in which the T2DM index is correlated with the ratio of T2DM patients and this system provides accurate classification of T2D individuals. For example, butyrate-producing bacteria may play a protective role against several types of diseases, and dysbiosis in T2DM patients may result from 'functional dysbiosis' rather than a specific microbial species.

\section{Susceptibility of T2D patients:-}

T2D patients are more susceptible to the diseases include macrovascular diseases (hypertension, hyperlipidemia, heart attacks, coronary artery disease, strokes, cerebral vascular disease, and peripheral vascular disease), microvascular diseases (retinopathy, nephropathy, and neuropathy) and cancers.

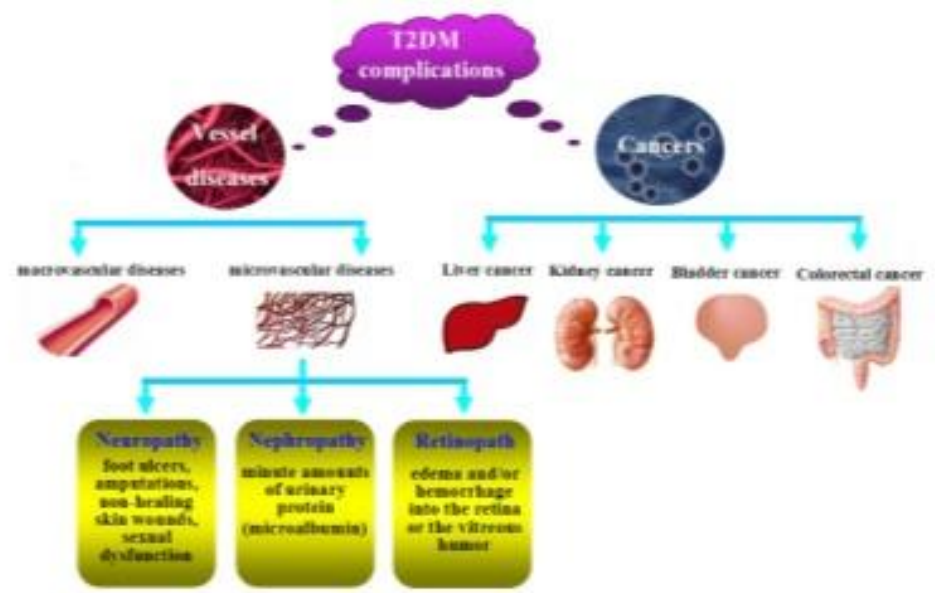

Figure 5:- T2D patient's susceptibility to disease. (20)(ijms.1185-1200.2014.). 
Care and Control on T2D:-

Recent studies suggested that proper care, efficient methods such as use of proper medication and therapy can reduce the prevalence of $\mathrm{T} 2 \mathrm{D}$.

\section{Vitamins and T2D:-}

Vitamin D:-

Current researchers supports that vitamin D may have a potential role in the control of T2DM $(22,23)$. A recent research shows that vitamin D deficiency may have negative effects on glucose intolerance, insulin secretion and T2DM (24), either directly via vitamin D receptor (VDR) activation or indirectly via calcemic hormones and also via inflammation $(25,26)$. As both 1 - $\alpha$-hydroxylase and VDR are present in pancreatic $\beta$ cells, vitamin D has significant roles in the synthesis and release of insulin. Furthermore, vitamin D has influence on the insulin sensitivity by controlling calcium flux through the membrane in both $\beta$ cells and peripheral insulin-target tissues (39). In addition, vitamin D supplementation is recognized as a promising and inexpensive therapy, which may decrease the risk of T2DM and improve glycemicparameters in T2DM patients (40). Therefore, it is seemingly that the positive effects of vitamin D are correlated with its action on insulin secretion and sensitivity as well as on inflammation.

\section{Vitamin K:-}

Vitamin $\mathrm{K}$ has two naturally occurring forms, including phylloquinone (vitamin K1) and menaquinones. Menaquinone-4 (vitamin K2) is considered as the active form of vitamin K in the bone tissue and functions in maintaining bone quality (41) and also as a transcriptional regulator of bone-specific genes that acts through steroid and xenobiotic receptors (SXRs) to promote expression of osteoblastic markers (42)It plays a protective role in bone fractures, in which the substance can promote $\gamma$-carboxylation of osteocalcin and induce production and secretion of osteocalcin by osteoblasts or may stimulate bone formation through SXRs. Besides, a recent survey indicates that vitamin K1 provides benefits in glucose homeostasis, as higher intake of vitamin K1 is correlated with greater insulin sensitivity and glycemic status (43). Because poor glycemic control and bone quality may occur when vitamin $\mathrm{K}$ is deficient, it is cardinal to exclude vitamin $\mathrm{K}$ deficiency in T2DM patients. Several preclinical and clinical observations show that vitamin $\mathrm{K} 2$ has effects on bone quality and subsequent bone mechanical strength in T2DM patients independently of increasing BMD(bone mineral density) $(44,45)$. It is also suggested that vitamin $\mathrm{K} 2$ may improve osteocyte density and lacunar occupancy by viable osteocytes in the cortical bone of glucocorticoidtreated or sciatic neurectomized rats $(46,47)$. In addition, vitamin K2 may down-regulate bone turnover and stimulate lamellar bone formation, and prevent an increase in bone resorption with maintaince of bone formation and prevent a decrease in lamellar bone formation in glucocorticoid-treated rats (48). Further studies are required for the comprehensive assessment of the role of vitamin $\mathrm{K}$ in the development of T2DM.

\section{Common antibiotic drugs for T2D control:-}

Different kind of antibiotic drugs are available for the control of T2D. Table 2 shows the drugs with their target ,action and disadvantage. $(49,50,51)$

Table 2:- Representative antidiabetic agents for the management of patients with T2DM (ijms.1185-1200.2014; 11(11):(20).

\begin{tabular}{|c|c|c|c|c|}
\hline Class & Drug (s) & Target & Action & Disadvantage \\
\hline Biguanides & Metformin & AMP-kinase & $\begin{array}{c}\text { blood glucose } \downarrow \\
\text { insulin sensitivity } \uparrow \\
\text { cardiovascular } \\
\text { risk } \downarrow \text { hypoglycemia } \\
\text { risk } \downarrow\end{array}$ & $\begin{array}{l}\text { G1 side effects } \\
\text { lactic acidosis } \\
\text { Vitamin B12 and } \\
\text { folate deficiency }\end{array}$ \\
\hline Sulfonylureas & $\begin{array}{c}\text { Glyburide/ } \\
\text { Glipizide/ } \\
\text { Gliclazide/ } \\
\text { Glimepiride }\end{array}$ & $\begin{array}{l}\text { ATP-sensitive, } K+ \\
\text { channels }\end{array}$ & insulin secretion $\uparrow$ & $\begin{array}{l}\text { hypoglycemia } \\
\text { weight gain }\end{array}$ \\
\hline TZDs & $\begin{array}{l}\text { Troglitazone/ } \\
\text { Roziglitazone/ } \\
\text { Pioglitazone }\end{array}$ & PPAR- $\gamma$ & $\begin{array}{c}\text { insulin sensitivity } \uparrow \\
\text { hypoglycemia risk } \downarrow \\
\text { glycemic control } \uparrow\end{array}$ & $\begin{array}{c}\text { bladder cancer } \\
\text { risk } \uparrow \text { weight gain } \\
\text { edema }\end{array}$ \\
\hline AGIs & $\begin{array}{c}\text { Acarbose/ Miglitol/ } \\
\text { Voglibose }\end{array}$ & $\alpha$-glucosidase & $\begin{array}{c}\text { carbohydrate } \\
\text { absorption } \downarrow\end{array}$ & $\begin{array}{c}\text { GI side effects } \\
\text { dosing frequency }\end{array}$ \\
\hline
\end{tabular}




\begin{tabular}{|c|c|c|c|c|}
\hline $\begin{array}{c}\text { GLP-1 receptor } \\
\text { agonists }\end{array}$ & $\begin{array}{c}\text { Exenatide/ } \\
\text { Liraglutide }\end{array}$ & GLP-1 receptors & $\begin{array}{c}\text { insulin secretion } \uparrow \\
\text { glucagon secretion } \downarrow \\
\text { satiety } \uparrow \\
\text { hypoglycemia risk }\end{array}$ & $\begin{array}{c}\text { GI side effects } \\
\text { acute pancreatitis } \\
\text { renal dysfunction } \\
\text { thyroid C-cell } \\
\text { tumors in rodents }\end{array}$ \\
\hline
\end{tabular}

New therapeutic strategies for control of T2D:-

When the oral insulin and anti diabetic agent not showing positive results there is a urgent need of therapeutic strategies for diabetic control. Many researchers suggested therapies for diabetic control $(52,53)$. These therapy includes Stem cell educator therapy, Antioxidant therapy, NO3-/NO2- therapy etc.

Some researchers focused on the some necessary life style interventions have beneficial for the control of T2D.

* Physical activity interventions.

* Healthy eating.

* Obesity management.

* Behaviour change interventions.

\section{Conclusions:-}

Today world facing a alarming situation due to increasing risk of T2D. The main cause of the diabetes epidemic is the interaction between genetic and environmental risk. A proper care and use of suggested measures can minimize the risk of T2D prevalence (54).T2DM and its related complications impose heavy health burdens worldwide and there have been not effective measures to fully cope with the diseases. There is a need to train a large number of grass-root health care workers to communicate with the rural population and the general public at large. A number of other factors are also attributable to the diseases. Whereas most antidiabetic agents have shown beneficial effects when used as monotherapy or combination therapy, they are also associated with negative effects, such as weight gain, hypoglycemia, gastrointestinal effects or cardiovascular disease. To date, several therapeutic strategies have been developed, such as the use of SGLT2 inhibitors, DPP-4 inhibitors and GPR40 agonists. Above all, stem cell educator therapy opened avenues to develop new therapeutic strategies in the treatment of T2DM, with safety and high therapeutic efficacy. Further investigations should focus on the exact mechanism contributing to T2DM and its related complications effective intervention trials and prevention measures to avoid the occurrence of this disease, earlier diagnosis for earlier treatment, novel drugs with more beneficial effects and less adverse effects, so as to conquer this disease and improve the quality of life and overall life span.

\section{References:-}

1. Ahmed, A.M (2002). History of diabetes mellitus. Saudi Medicine 23 (4): 373-378.

2. Pathak.(2002). New weapons to combat an ancient disease: treating diabetes. FASEB Journal 16 (14):18-53.

3. Staiger, $\mathrm{H}$ and Machicao, F (2009). Association of type2 diabetes genes in Beta cell dysfunction. Diabetes 58: 1715-1720.

4. Sladek R, Rocheleau G, Rung J, et al. A genome-wide association study identifies novel risk loci for type 2 diabetes. Nature. 2007; 445(7130): 881-885.

5. Jason Flannick and Jose C. Florez(2016).Genetic data sharing to advance complex disease research .Nature Reviews Genetic 17:535-54.

6. van Exel E, Gussekloo J, de Craen AJ, et al. Low production capacity of interleukin-10 associates with the metabolic syndrome and type 2 diabetes: the Leiden 85-Plus Study. Diabetes. 2002; 51(4): 1088-1092.

7. Hua Y, Shen J, Song Y, et al. Interleukin-10-592C/A, -819C/T and -1082A/G polymorphisms with risk of type 2 diabetes mellitus: A HuGE review and meta-analysis. PLoS One. 2013; 8(6): e66568.

8. Olokoba AB, Obateru OA, Olokoba LB. Type 2 diabetes mellitus: a review of current trends. Oman Med J. 2012; 27(4): 269-273.

9. Lyssenko V, Nagorny CL, Erdos MR, et al. Common variant in MTNR1B associated with increased with risk of type 2 diabetes and impaired early insulin secretion. Nat Genet. 2009; 41(1): 82-88.

10. Sanghera DK, Ortega L, Han S, et al. Impact of nine common type 2 diabetes risk polymorphisms in Asian Indian Sikhs: PPARG2 (Pro12Ala), IGF2BP2, TCF7L2 and FTO variants confer a significant risk. BMC Med Genet. 2008; 9: 59.

11. Frayling TM, Timpson NJ, Weedon MN, et al. A common variant in the FTO gene is associated with body mass index and predisposes to childhood and adult obesity. Science. 2007; 316(5826): 889-894. 
12. https//www.ncbi.nim.nih.gov/pmc/articles/PMC3057517/pdf/nihms-248743.pdf.Ann N Y A Sci.Author manuscript; available in PMC 2011 Nov.1.

13. response to a threat: http://www.diabetesselfmanagement.com/Blog/David-Spero/reducing_stress.

14. isolationisincreasing:http://www.washingtonpost.com/wpdyn/content/article/2006/06/22/AR2006062201763.ht $\mathrm{ml}$.

15. Loneliness: http://www.huffingtonpost.com/2014/02/18/loneliness-obesity-premature-death-studychicago_n_4807872.html.

16. written here before: http://www.diabetesselfmanagement.com/Blog/David-Spero/toxic-chemicals-and-diabetes.

17. Eze,I.C.,E.,Fisher,E.,Schikowski,T.,Adam,M.,Imboden,M.,et al.,2014a. Long -term exposure to ambient air pollution and diabetes in a population-based Swiss cohort. Environ.Int.70.95-105.

18. Park,S.K.,O’Neil,M.S.,Wright,R.O.,Hu,H.,Vokonas,P.S.,Sparrow,D.,et al.,2015.Long-term exposure to air pollution and type 2 diabetes mellitis in a multietinic Cohort.Am.J.Epidemiol.181,327-3045.

19. Rao.X.,Montresor-Lopez,J.,Puett.R.,Rajagopalan.S.,Brook,R.D.,2015.Ambient air pollution:an emerging risk factor for diabetes mellitis.Curr.Diabetes Rep.15.603.

20. Yanling Wu1, Yanping Ding Yoshimasa Tanaka and Wen Zhang Risk Factors Contributing to Type 2 Diabetes and Recent Advances in the Treatment and Prevention : 2014; 11(11): ijms.1185-1200.

21. Stephania T. Miller, David G. Schlundt, James W. Pichert and Nasar U. Ahmed, Shaping Environments for Reductions in Type 2 Diabetes Risk Behaviors: A Look at CVD and Cancer interventions.(Diabetes Spectrum 2002(15).

22. Zimmet P, Alberti KG, Shaw J. Global and societal implications of the diabetes epidemic. Nature. 2001; 414(6865): 782-787.

23. Hu FB, Manson JE, Stampfer MJ, et al. lifestyle, and the risk of type 2 diabetes mellitus in women. N Engl J Med. 2001; 345(11): 790-797. 40.

24. Manson JE, Ajani UA, Liu S, et al. A prospective study of cigarette smoking and the incidence of diabetes mellitus among US male physicians. Am J Med. 2000; 109: 538-542.

25. Cullmann M, Hilding A, Östenson CG. Alcohol consumption and risk of pre-diabetes and type 2 diabetes development in a Swedish population. Diabet Med. 2012; 29(4): 441-452.

26. Belkina AC, Denis GV. Obesity genes and insulin resistance. CurrOpinEndocrinol Diabetes Obes. 2010; 17(5): 472-477.

27. Walley AJ, Blakemore AI, Froguel P. Genetics of obesity and the prediction of risk for health. Hum Mol Genet. 2006; 15 (Spec No 2): R124-R130.

28. Pamidi S, Tasali E. Obstructive sleep apnea and type 2 diabetes: is there a link? Front Neurol. 2012; 3: 126. 45. Ioja S, Weir ID, Rennert NJ. Relationship between sleep disorders and the risk for developing type 2 diabetes mellitus. Postgrad Med. 2012; 124(4): 119-129. 46.

29. Lindberg E, Theorell-Haglöw J, Svensson M, et al. Sleep apnea and glucose metabolism: a long-term follow-up in a community-based sample. Chest. 2012; 142(4): 935-942.

30. Mitri J, Dawson-Hughes B, Hu FB, et al. Effects of vitamin D and calcium supplementation on pancreatic $\beta$ cell function, insulin sensitivity, and glycemia in adults at high risk of diabetes: the calcium and vitamin D for diabetes mellitus (CaDDM) randomized controlled trial. Am J ClinNutr. 2011; 94(2): 486-494. 61.

31. Schober AK, Neurath MF, Harsch IA. Prevalence of sleep apnoea in diabetic patients. ClinRespir J. 2011; 5(3): 165-172. 49 .

32. van Dam RM, Willett WC, Rimm EB, et al. Dietary fat and meat intake in relation to risk of 2 diabetes in men. Diabetes care. 2002; 25(3): 417-424.

33. Liu S, Manson JE, Stampfer MJ, Hu FB, et al. A prospective study of whole-grain intake and risk of type 2 diabetes mellitus in US women. Am J Public Health. 2000; 90(9): 1409-1415.

34. Nikooyeh B, Neyestani TR, Farvid M, et al. Daily consumption of vitamin D- or vitamin D + calcium- fortified yogurt drink improved glycemic control in patients with type 2 diabetes: a randomized clinical trial. Am J ClinNutr. 2011; 93(4): 764-771.

35. Pittas AG, Sun Q, Manson JE, et al. Plasma 25-hydroxyvitamin D concentration and risk of incident type 2 diabetes in women. Diabetes Care. 2010; 33(9): 2021-2023.

36. Thorand B, Zierer A, Huth C, et al. Effect of serum 25-hydroxyvitamin D on risk for type 2 diabetes may be partially mediated by subclinical inflammation: results from the MONICA/KORA Augsburg study. Diabetes Care. 2011; 34(10): 2320-2322. 64.

37. Chagas CE, Borges MC, Martini LA, et al. Focus on vitamin D, inflammation and type 2 diabetes. Nutrients. 2012; 4(1):52-67. 
38. Qin J, Li Y, Cai Z, et al. A metagenome-wide association study of gut microbiota in type 2 diabetes. Nature. 2012; 490(7418): 55-60.

39. Wolden-Kirk H, Overbergh L, Christesen HT, et al. Vitamin D and diabetes: its importance for beta cell and immune function. Mol Cell Endocrinol. 2011; 347(1-2): 106-120.

40. Takiishi T, Gysemans C, Bouillon R, et al. Vitamin D and diabetes. EndocrinolMetabClin North Am. 2010; 39(2): 419-446.

41. Iwamoto J, Takeda T, Sato Y. Effects of vitamin K2 on osteoporosis. Curr Pharm Des. 2004; 10: 2557-2576. 69.

42. Tabb MM, Sun A, Zhou C, et al. Vitamin K2 regulation of bone homeostasis is mediated by the steroid and xenobiotic receptor SXR. J Biol Chem. 2003; 278(45): 43919-43927.

43. Yoshida M, Booth SL, Meigs JB, et al. Phylloquinone intake, insulin sensitivity, and glycemic status in men and women. Am J ClinNutr. 2008; 88: 210-215.

44. Iwamoto J, Takeda T, Sato Y. Menatetrenone (vitamin K 2) and bone quality in the treatment of postmenopausal osteoporosis. Nutr Rev. 2006; 64: 509-517.

45. Kobayashi M, Hara K, Akiyama Y. Effects of vitamin K2 (menatetrenone) and alendronate on bone mineral density and bone strength in rats fed a low-magnesium diet. Bone. 2004; 35: 1136-1143.

46. Iwamoto J, Matsumoto $\mathrm{H}$, Takeda $\mathrm{T}$, et al. Effects of vitamin $\mathrm{K} 2$ and risedronate on bone formation and resorption, osteocyte lacunar system, and porosity in the cor-tical bone of glucocorticoid-treated rats. Calcif Tissue Int. 2008; 83: 121-128.

47. Iwamoto J, Matsumoto H, Takeda T, et al. Effects of vitamin $\mathrm{K} 2$ on cortical and cancellous bone mass, cortical osteocyte and lacunar system, and porosity in sciatic neurectomized rats. Calcif Tissue Int. 2010; 87: 254-262.

48. Iwamoto J, Seki A, Sato Y, et al. Vitamin K2 promotes bone healing in a rat femoral osteotomy model with or without glucocorticoid treatment. Calcif Tissue Int. 2010; 86(3): 234-241.

49. Bourdel-Marchasson I, Schweizer A, Dejager S. Incretin therapies in the management of elderly patients with type 2 diabetes mellitus. HospPract (Minneap). 2011; 39: 7-21.

50. American Diabetes Association. Standards of medical care in diabetes-2012. Diabetes Care. 2012; 35 (Suppl 1):S11-S63.

51. Ahren B. Are sulfonylureas less desirable than DPP-4 inhibitors as add-on to metformin in the treatment of type 2 diabetes? CurrDiab Rep. 2011; 11: 83-90.

52. Scheen AJ. Linagliptin plus metformin: a pharmacokinetic and pharmacodynamic evaluation. Expert Opin Drug MetabToxicol. 2013; 9(3): 363-377.

53. Bell DS. Combine and conquer: advantages and disadvantages of fixed-dose combination therapy. Diabetes ObesMetab. 2013; 15(4): 291-300.

54. Abdul-Ghani MA, Abdul-Ghani T, Ali N, et al. One-hour plasma glucose concentration and the metabolic syndrome identify subjects at high risk for future type 2 diabetes. Diabetes Care. 2008; 31(8):1650-1655.

55. Grant RW, Moore AF, and Florez JC. Genetic architecture of type 2 diabetes: recent progress and clinical implications. Diabetes Care. 2009;32(6):1107-1114.

56. Diabetes Prevention Program Research Group. 10-year follow-up of diabetes incidence and weightlossin the Diabetes Prevention Program Outcomes Study. Lancet. 2009;374(9702):1677-1686. 